\title{
Visual communication in research: a third space between science and art
}

\author{
Laura Corazza ${ }^{\mathrm{a}}$, Anita Macauda ${ }^{\mathrm{b}}$ \\ ${ }^{a}$ University of Bologna, Italy, laura.corazza@unibo.it, https://orcid.org/0000-0002-0351-3771 \\ ${ }^{b}$ University of Bologna, Italy, anita.macauda@unibo.it, https://orcid.org/0000-0003-1522-5440
}

\begin{abstract}
Ample scientific literature recognises the role of visual thinking in the constructive process of ideas and mental images and the function of visual intelligence in the communicative processes. Starting from the sectoral studies, we have turned our attention to the visual communication of the results of scientific research, relating it to some characteristics of artistic communication to find a shared ground, that is, a third space inhabited by common languages and competencies. In so doing, we have overcome the traditional antinomy between humanists and scientists, starting instead from the results of a recent study that has shown how such an opposition does not find real confirmation in the sector of science communication. We have thus analysed three case studies (graphical abstract, augmented reality, audiovisual documentation) on the grounds of a 10-year long experience of research in the field of visual communication (iconography and iconology, art teaching, video research) to acknowledge visual thinking and graphicallartistic competencies, situated in the third space between didactics and art, a fundamental role in the formation of a scientist and a researcher.
\end{abstract}

Keywords: visual intelligence; scientific research; visual communication; third space

\section{Intelligence and visual communication}

Sectoral studies show how visual perception is closely connected to the mental processes of exploration and selection: these are two activities that come into play when we visually perceive the elements of a context. The gaze is positioned on one object rather than another, thanks to the attention mechanism (Shams \& Kim, 2010; Lumbelli, 2012). The visual elements thus perceived then enrich the subject's cognitive structure, conditioning the successive perceptive act, in a continuous process that involves the eyes and the mind together: perceiving and thinking are two interconnected moments that call for an active engagement of the mind, so that it can be stated that visually perceiving is thinking visually. Visual intelligence grasps in the context single visual elements that are associated with mental categories, proceeding by way of resemblances and associations (Cicalò, 2016; Panciroli, Corazza \& Macauda, 2020). The objects and concepts are associated with patterns of reference, becoming full-fledged mental images. The process is influenced by emotive involvement: the more meaningful the experience, the more efficacious the perceptive experience is and the more long-term memorisation is facilitated. As in impressionist painting, the images are not the photograph of the real, but the result of impressions, that is, of a selective and perceptive process conducted through the emotions (Arnheim, 1974, 1984). In this sense, such a process enriches the cognitive structure, thus configuring itself as a full-fledged form of thinking and intelligence. Visual thinking has in its elaborative-constructive function the most interesting aspect of the individual's cognitive growth, as it allows for the creation of mental images of the facts. Indeed, the visual instruments enable us to communicate and, at the same time, structure ideas; examples of this are the mental and conceptual maps, graphs, tables and diagrams, animations, simulations and virtual realities (Floridi, 1998).

Moreover, visual thinking not only elaborates perceptive data, but also creates new structures that, in turn, have a generative power vis-à-vis ideas. Indeed, the image is an interpretative model and not a faithful representation; for this reason, visual thinking is closely connected with the creative processes. Specifically, the scientific literature highlights how the creative process, associated with the activities involving visual thinking, can be supported and developed in situations of search for solutions to new problems, such as in the strategy of problem-based learning. In fact, visual representations 


\section{Visual communication in research}

Corazza, L., Macauda, A.

allow to use a metaphorical language that generates new universes of meaning and is functional to support creative flexibility (Cheung, 2011; Ulger, 2018).

With reference to the theory of multiple intelligences articulated by Gardner (1983), visual intelligence is positioned in a relationship of complementariness with graphic intelligence: it defines the cognitive abilities connected to the imagination and capacity of 'thinking by images', that is, to mentally portray the concepts even before verbalizing them, allowing one to make an immediate experience of the world; graphic experience concerns the capacity to integrate perception, thinking and representation of reality to create artefacts finalised to the acquisition and construction of new knowledge (Robertson, 2003; Cicalò, 2016; Fiorentino, 2018). The vision/production of an image allows the student to activate cognitive explorative processes - those of categorisation, memory, prediction, comprehension, emotion and empathy (Calvani, 2011). In this regard, Clark and Lyons (2010), in identifying some functions of the images concerning attention, activation of knowledge, minimization of cognitive load, support to motivation and, in particular, the images, can exert a function of mediation, anticipation and modelling in respect to knowledge (Rivoltella, 2014).

Visual codification is generative of concepts and meanings in every field of knowledge, for communicative, creative use as well as memorisation and personal re-elaboration. Architects and engineers visualize before building and this is functional to the design; scientists use systems of visualisation of the data to highlight concepts' bonds. Students create conceptual maps to clarify and memorize facts and ideas, relating them to one another to interpret, re-elaborate and convey knowledge visually. A map has a hierarchical structure that involves all the elements of the object of communication: the pivotal concepts, the ties between these and the overall path of reasoning. But it can also have a reticular structure, rich in connections. It is, indeed, the visual architecture that makes the map a creative product, thanks to which knowledge is enriched with new stimuli and elements: each graphic image rendered by the map, with its foregrounds, the colours, forms, equilibriums, aesthetic criteria, identifies a new structure inside concepts that are already known (see Fig. 1). Indeed, for the same contents, different people are able to create different visual and meaning architectures, overcoming the simple idea of a chart (Panciroli, Corazza \& Macauda, 2020). In a map thus conceived, the visual organization of the elements corresponds to the logical and functional structure of one's own knowledge; indeed, different architectures allow one to explore the many standpoints from which one same phenomenon can be analysed and to highlight diverse, simple or complex structures, with different levels of expositional clarity and communicative efficacy. Constructing a map reduces the likelihood of mechanical learning in favour of an active/meaningful learning, stimulating the process of learning to learn. Giving knowledge a personal organization, different from who presented it previously, allows for an awareness of different learning styles, reflecting on one's own mental processes and allowing for reciprocal remediation (Novak, 2001, 2012; Trentin, 2015; Pellegrini \& Mensuali, 2015; Marzano, 2017).

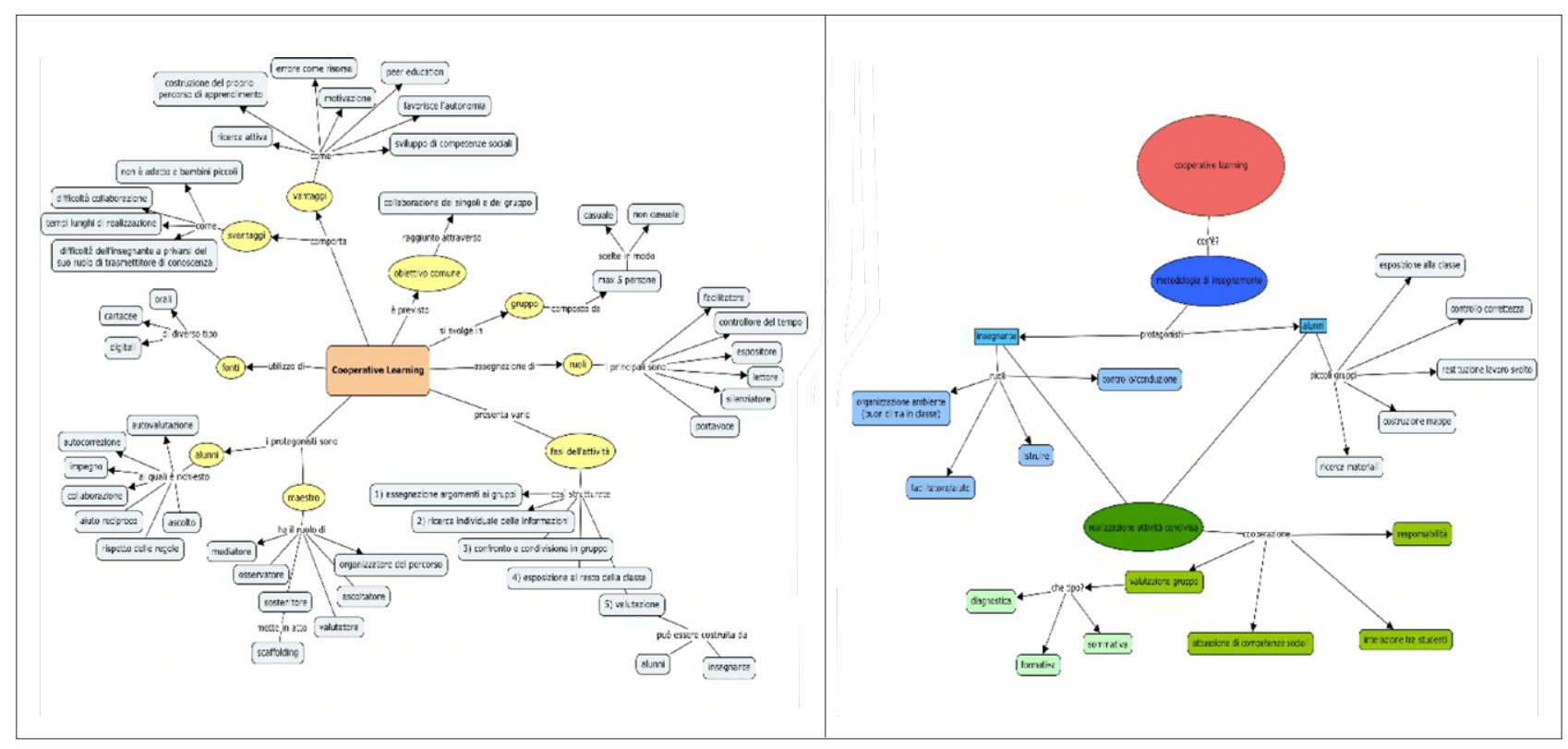

Fig. 1 Cognitive maps elaborated by two different groups of students in a laboratory of didactic technologies at the Department of Education Sciences of Bologna University

The repercussions on learning are well-known and multiple and are particularly evident when the maps created in different educational contexts are analysed. The students' age, the diverse capacity for learning and managing complex knowledge, and the different styles of learning and organization of knowledge are expressed very well by the kind of structure chosen to construct the conceptual map. Digital maps differ from one another in many ways, like the style chosen on the grounds of the target audience, aspects of trait and colour, complexity of the connections and adequacy of the choices in relation to the objectives. In this regard, a study conducted in 2015 drew attention to the learning results in relation to the use of various instruments for the digital presentation of the contents (Chiou et al. 2015), showing how dynamic systems of representation positively influence the acquisition of knowledge by the students. These aspects show 
how visual communication is composed of multiple levels, variable in relation to the typology of support/medium through which the information is diffused, and the specificity of the visual language, comprising formal and chromatic elements, which, variously arranged on a surface, determine oppositions and transformations of values contributing to constructing the semantic content of an image (Greimas, 1984; Calabrese, 1984).

Starting from the assumption that communication is one of the primary functions of art, by virtue of its potential universality and its being intrinsically expressive (Dewey, 1934), what was argued by Munari $(1968,1971)$ with regard to the communicative function of visual language results to be particularly significant. In fact, according to Munari, everything that can be told at the chiefly visual level (and the range of possibilities goes from the scheme of an electrical circuit to a work of art) constitutes a visual communication; however, in order for the message implicit in it to be received, the recipient needs opportune cultural filters that allow it to be decodified and absorbed. 'The cultural level of a certain mass of public to whom certain information is to be given, should be considered but not in the sense in which many advertisers still do today: they indeed argue that as a certain category is not very intelligent, they need to be given stupid messages. Perhaps they should be given far clearer messages, which often involves greater research work' (Munari, 1968, p. 166). With reference to these requirements, Munari defines aesthetic or visual operators as those who make visual communications: graphic artists, advertisers, photographers, video makers, designers, illustrators, etc. The characteristics that the aesthetic operator must possess are closely connected to the speed of realization, flexibility and adaptability; desirable is not so much the possession of abilities in specific techniques, but rather the knowledge of the basic principles of visual language (forms, textures, structures, contrasts, colours, lights, etc.) to be declined according to the message that one has to convey from one time to the next.

\section{Visual communication for scientific research}

The practice of visual representation of the results of scientific research has ancient origins and answers to the need to systematise the knowledge available to the researchers to highlight intersections and relations, known and hidden elements, and to communicate in an effective and involving manner. In the course of time, this practice has evolved, also thanks to the transformation of the instruments of graphic elaboration and the capacity of the individuals to elaborate, codify and interpret visual messages. Let us take two historical cases by way of example.

\subsection{The map that changed medicine}

The physician John Snow discovered that cholera spread by means of polluted water. In 1855, in the London neighborhood of Soho, there was a very serious outbreak of cholera that the physician related to the presence of a pump that distributed sewage-contaminated water. He came to that conclusion, also thanks to the drawing of a map that illustrated the geographical distribution in the neighborhood of cases of cholera, highlighting how the incidence was higher close to the public water pump of Broad Street (see Fig. 2). To link the incidence of cholera to the potential geographical sources, he made a diagram, which is known today as the Voronoi diagram (see Fig. 3). He mapped the single water pumps and identified some cells that represented all the points on his map that were closest to each water pump. He discovered that the areas of the city closest to the Broad Street pump were the ones with the highest number of cholera cases (Jefferson, 2007).
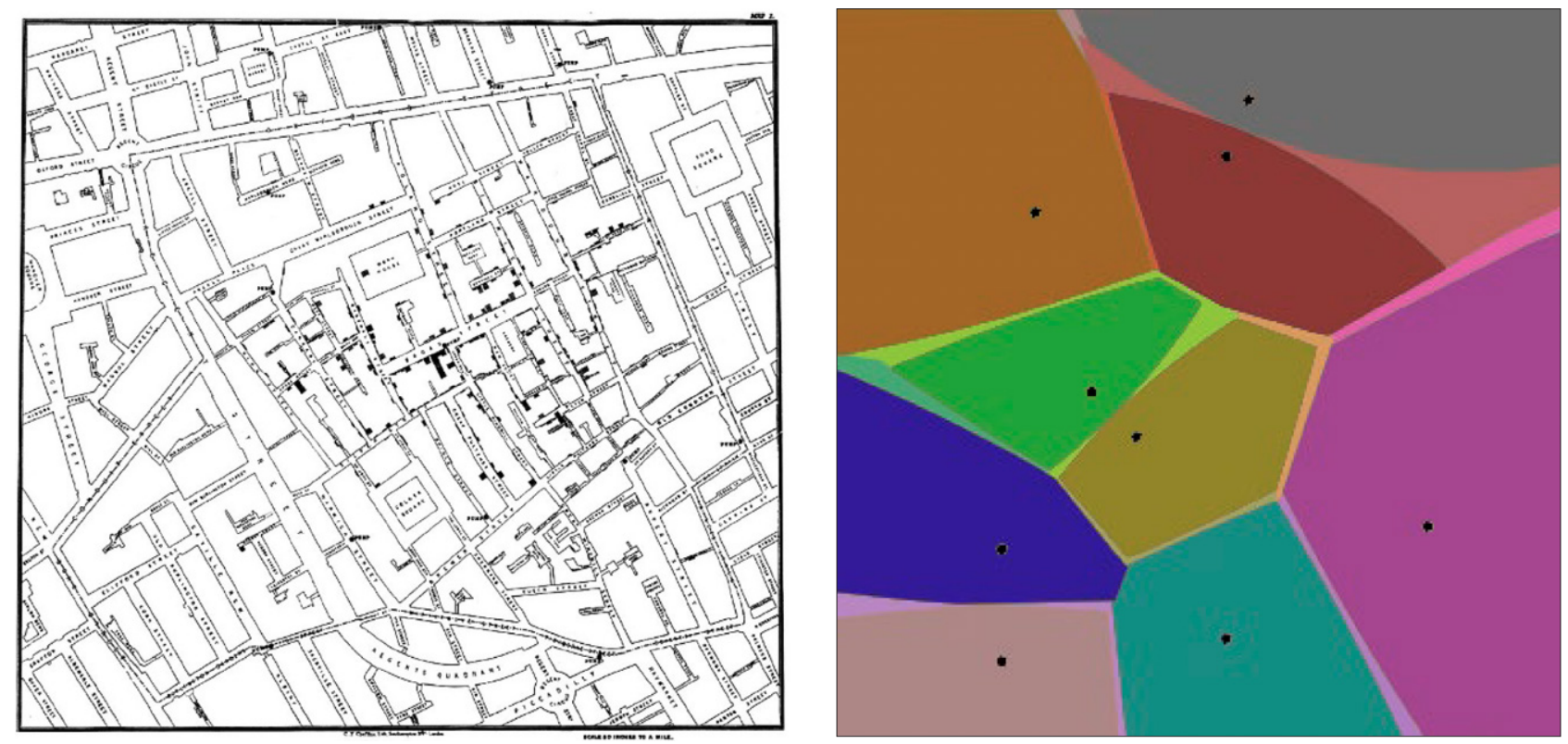

Figs 2 and 3 The original map by John Snow and Voronoi diagram approximated (from Wikipedia)

Research on Education and Media. Vol. 13, N. 2, Year 2021 - ISSN: 2037-0830 
Visual communication in research

Corazza, L., Macauda, A.

\subsection{The periodic table of the elements by Mendeleev}

By means of the position of the cells and the differentiation by colour, the periodic table shows the chemical characteristics of the elements. Mendeleev had discovered that a periodicity is evidenced by positioning the chemical elements in rising order on the grounds of their atomic masses. He also predicted some properties of unidentified elements that were expected to fill gaps within the table (Ciardi, 2019). This is an example of generative function of the image: the position and the colours have revealed concepts that were not visible before, also obtaining the result of conveying them with greater efficacy and making them easier to memorize. Besides the classical and better-known version of Mendeleev's periodic table, around 800 graphically different versions have been published; some maintain the rectangular format, others develop starting from more or less complex forms: circular, cubic, cylindrical, helix shaped, the symbol of infinity, octagonal prism, pyramidal, separated, spherical, spiral shaped, triangular. The forms are chosen to highlight certain chemical and physical properties in a different way from the original table ${ }^{1}$.

\section{Visual communication for scientific research today: three case studies}

Having analysed the literature of reference and having oriented the research and teaching of the last 10 years towards the use of forms of visualisation for scientific and didactic communication (Panciroli, 2020; Panciroli \& Macauda, 2018, 2019; Panciroli, Macauda \& Corazza, 2020; Corazza, Reggiani, Ferrari, Nenzioni \& Mäkelä, 2018; Corazza, 2017; Corazza \& Ferrari, 2012; Corazza, 2010, 2012), we have chosen three types of graphic/visual products for the communication of the research that we believe to be exemplary in respect to common practice. We feel that honing the analysis of these cases can be useful for configuring a perspective of development and identifying strategies of intervention within the scope of visual communication. A recent study has shown how the communication of research affects all the sectors of science, from the scientific fields to the humanities and social ones, in an equally distributed with some apt differentiations, especially in the relations with the public at large (Scamuzzi, 2015; Tipaldo \& Carriero, 2015). The cases that we have chosen are thus to be understood as being applicable to all the research fields, in our view.

\subsection{The graphical abstract}

Used above all by the scientific journals, and already in use in the humanities sector, the graphical abstract is a combination of figures and texts that converts into graphic/visual format the abstract of the article, highlighting the main themes dealt with and, at times, the narrative structure. It can be made by following the style of a diagram, an illustrated map of infographic. The advantages are the possibility to quickly channel the contents and draw attention to them, reaching out a vaster public; the graphical abstracts can be searched for as images by the search engines via the key words of the title, thus allowing the user to subsequently trace the whole contribution (Pferschy-Wenzig, Pferschy, Wang, Mocan \& Atanasov, 2016).

To be effective, they must allow the reader to grasp the main messages of the scientific contribution, with the aims of arousing curiosity, encouraging reading and further analysis; they must have a clear beginning and an end to reduce as much as possible the elements of distraction ${ }^{2}$.

The logical processes to construct a visual abstract are of three types. At first, there is the work of conceptualisation, which means making a lots of concepts relating to the main message of the text, in relation to the type of audience being addressed; in the second place, it is necessary to draw the overall structure of the narrative and, thirdly, choose the images of reference. All the visual elements should be connected with one another in some wat and ordered in groups by affinity, using an aesthetic style as far as possible in a uniform manner. The coherence of the design, the distribution of the concepts in the space in an organised way and the evidence of bonds of structures, indeed, contribute to channelling the messages clearly and quickly, with a generative power vis-à-vis the meanings and the reflexivity by the reader. Also, the aesthetic yield, with a good use of colours, forms, structures, contrasts, conditions the communicative success that, in part, can be assimilated to that of an art work and of its expressive form. This means of presentation of the contents, born in the scientific domain, is also contaminating other research fields such as the social humanities one (Lane, Karatsolis \& Bui, 2015; Wray \& Arora, 2017; Hullman, \& Bach, 2018; Ibrahim, 2018).

The production of a visual abstract for the congress Graphics/Grafiche - International and Interdisciplinary Conference on Images and Imagination ${ }^{3}$, and that saw the participation of researchers from different disciplines, stimulated us in the reflection on the utility of this language. The final product asked of us by the organizers of the congress had to be composed of a graphic part associated with a short-written contribution. The result was two pages that had different functions: anticipating the contents of the presentation to those who would take part in the congress; making an outline for the presentation during the proceedings and communicating the congress after its conclusion (see Fig. 4).

\footnotetext{
${ }^{1}$ From Wikipedia https://it.wikipedia.org/wiki/Tavola_periodica_degli_elementi

${ }^{2}$ From the instructions to the authors of Elsevier https://www.elsevier.com/authors/tools-and-resources/graphical-abstract

${ }^{3}$ Congress held in Alghero in July 2019 http://www.img-network.it/conference-2019/
} 
Visual communication in research

Corazza, L., Macauda, A.

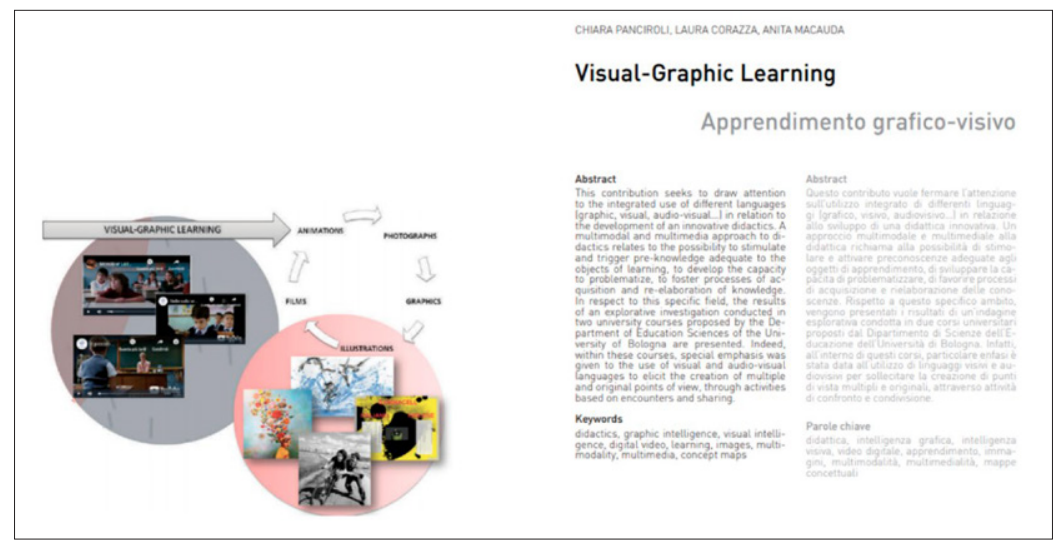

Fig. 4 Graphical abstract for a congress

\subsection{Augmented reality}

Today, augmented reality represents an innovative ambient of scientific communication through the use of digital information (of a verbal, visual, audiovisual nature) overlapping the physical world. A basic principle that presides over augmented reality is that of the overlay. The camera of any digital device (tablet, netbook, smartphone, etc.) reads the framed object; the system recognises it and activates a new level of communication that overlays and perfectly integrates the reality, enhancing the quantity of data needed to read and deepen the nature of the object. Thus, augmented reality allows us to design new systems of visualisation and spatial representation of complex data, with a consequent immersive effect, capable of involving sensoriality and corporeity in different forms (Nah \& Lee, 2016; Macauda, 2018, 2020; Miranda \& Marzano, 2019). Indeed, the superseding of the bidimensional support involves a different observational approach, as well as a new type of interaction and an experience of knowledge by the subject. In this sense, the use of augmented reality is situated for the communication of contents of the scientific field (Salmi, Thuneberg \& Vainikainen, 2017; Giunta, Ben Guefrache, Dekoninck, Gopsill, O’Hare \& Morosi, 2019). In the specific case, here we refer to communication by means of augmented reality of objects (in particular, the instruments used by scientists, the products of their research, etc.) pertaining to different areas (such as physics, anatomy, optics), conserved in the ancient rooms of the Institute of Sciences of Bologna University, the present-day Museo di Palazzo Poggi. Through a dedicated visor, the augmented reality proposes a new space of communication of information, anchored to the physical context, related to the history of the Palazzo and its collections, supplemented with texts of a visual nature that allow one to access details that are otherwise very hard to identify, as well as the materiality of the objects by means of 3D reconstruction.

Analogously, the Museum of the Sciences of Trento (MUSE), has set up a new system of communication in augmented reality through the app GO!Muse. The augmented milieu offers in this case the possibility to see what the prehistoric animals housed by the museum (dinosaurs, prehistoric reptiles and whales) looked like and how they moved and whose physiognomy has been reconstructed, thanks to the collaboration between the researchers of the MUSE and the paleo artists Davide Bonadonna and Fabio Manucci, who have transformed the indications of the MUSE researchers into animated images (see Fig. 5).

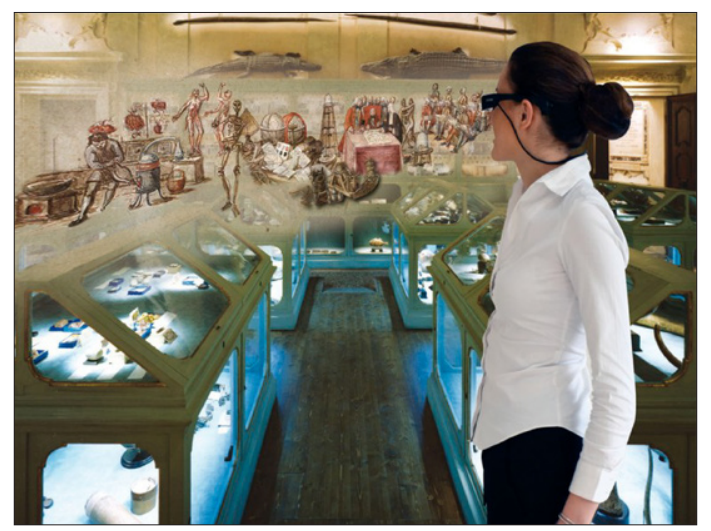

Fig. 5 Pathways in augmented reality, Sala di Ulisse Aldrovandi, Palazzo Poggi

\subsection{Digital video}

Audiovisuals are potential instruments for the development of different cognitive styles as they elicit the diverse sensorial modalities of perception and elaboration of the informational data: texts, images and sounds are interwoven in a video and 
are merged, thus creating a multimodal moment of knowledge representation. What is meant by the term audiovisual today? The question does not have a univocal answer and recalls different cultural horizons. The online Treccani Italian dictionary highlights the dual function, masculine noun and adjective of the Italian term 'audiovisivo' and refers to what 'allows one to see and hear at the same time', also in relation to the message that the means bears with it. The term audiovisual seems to bear with it a broader meaning in respect to video and film. Understood as a qualifying adjective, it shifts the focus from the technological means and from its various products (the machines and the texts) towards what is today believed to be the true novelty, the advent of a new language, which is transforming communication and culture (Lever, 2019).

It is, indeed, the concept of language that shifts the focus from the audiovisual object to the audiovisual conversation and the audiovisual text, contemplating a phenomenal peculiarity of the digital media formats inserted in a communicational system that has been totally renewed today by the Web. The Web platforms for publishing and sharing have turned video into a product that is also widely used for the personal production of contents. The digital format associated with the potential of the Internet has created a virtuous process in terms of convergence of virtual places and resources, and it multiplies the opportunities for diffusion and utilisation. The screens from which it can be seen are almost endless, of many shapes and sizes, mobile or desktop, with a greater or lesser number of possible interactions, but are never one directional. Part of the structure and the philosophy of the digital videos on the Web is the chance to create interconnections or to comment and make evaluations, thanks also to YouTube which transforms a simple audiovisual product into a cultural object having multiple characteristics. A digital video published on a YouTube channel is a straightforward object; a digital video published on a YouTube channel with a network of comments and links is a different product; a digital video published on a YouTube channel with a network of comments and inserted in a Web page or in an online course is again a different object (Panciroli, Corazza \& Macauda, 2019; Corazza, 2017; Reggiani, Ferrari, Nenzioni \& Mäkelä, 2018; Corazza \& Zanchettin, 2016).

Within the scope of the project BIOAPI-OER ${ }^{4}$, we have produced short audiovisuals that document an activity of research and laboratory practices, for the qualitative analysis on honey and its by-products, and multimedia didactic lessons. The products aim to be reused and readapted for possible future uses, according to the logic of open-access online resources, as they are released with creative commons licence. For this reason, we have chosen them as study cases for the visual communication of science (see Fig. 6).
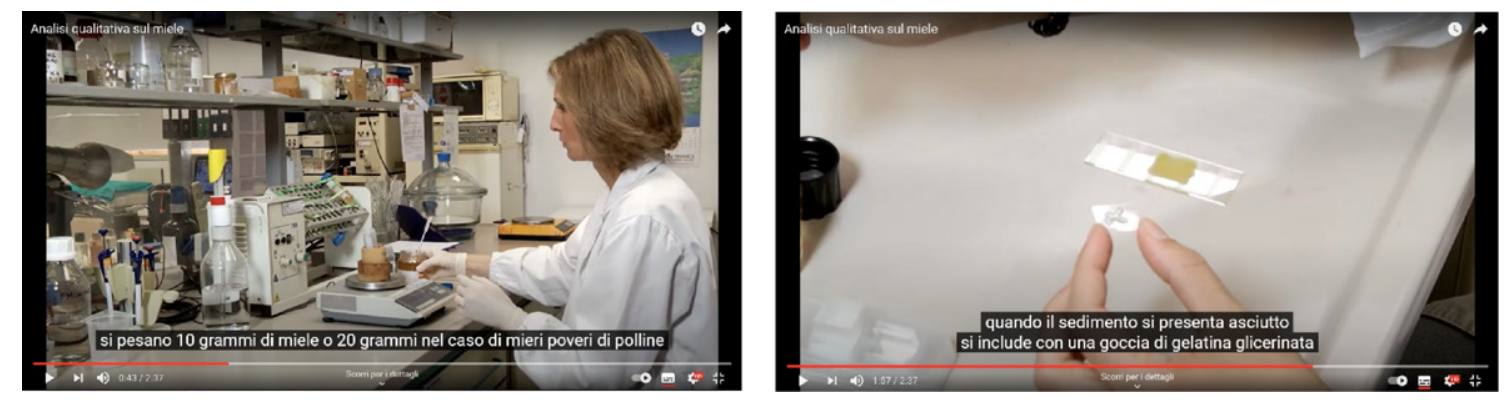

Fig. 6 Two frames of a documentary video on the practices of honey analysis

\section{The educational challenge: meeting in the third space}

The visualisation of the contents of scientific research responds to the need to structure the data in a chart and in a representation to convey them (Latour, 2011; Evagorou, Erduran \& Mäntylä, 2015). This not only requires scientific competencies to structure the data and present them clearly and efficaciously, but also creative competencies. In the visual representation, aesthetics and functionality must be integrated, highlighting in an immediate way key aspects, relations and contexts. Aesthetics is not an end unto itself, but has the function of improving the perception of the message without ever compromising the contents and stimulating the curiosity of knowing (Elgendi, 2017; Nayak \& Iwasa, 2019).

The educational challenge is the training of researchers who master, besides drafting complex scientific texts, also a more immediate, but equally scientific narrative genre, rapid and involving, but at the same time rigorous. A third narrative way or 'third space' (Gutiérrez, 2008; Flessner, 2014) has the characteristics of the scientific paper and visual communication together. Drawing inspiration from the tradition of the sciences, such a language should avail itself in a preponderant way of the graphic-visual forms. The open-access digital scientific journals, on the one hand, and the predominance of visual communication on the Web, in the shape of animations, videos or augmented reality, on the other, stimulate the scholars and specialists to master the new conceptual, interpretative and technical-communicative instruments. The problem is that the researchers rarely have a sufficient level of literacy to be able to interpret and create graphic products and to be able to use visual communication in a competent way (Williams \& Newton, 2007).

The alternative is represented by the training of visual operators, capable of immersing themselves in every scientific theme and interpreting it with the visual language, enriching the narrative of the researchers without distorting it. To do

\footnotetext{
${ }^{4}$ The project BIOAPI-OER aims to develop a short online course, with free access, on the theme of bees as environmental bioindicators. By means of interdisciplinary scientific cooperation between the Universidad del Sur (Argentina), the University of Bologna, the CREA (Bologna) and the group CSA (research institute), the project aim concerns devising and implementing a 20-hour online training pathway https://site.unibo.it/bioapi/it
} 
so, they should be able to rapidly grasp the main concepts to be conveyed, without having, however, the instruments with which to master the discipline. They should learn to structure the concepts according to hierarchies and make emerge the structures by means of efficacious expressive instruments. These are professional figures capable of mastering the strategic function of the scientific communication, addressing as wide an audience as possible and at the same time competent in the techniques and the graphic-visual formats. This aspect opens the way, however, to the issue of methodological rigour, which the theme of visualisation of scientific research brings with it: the visual operator has the obligation to approach the data without compromising its scientific and the conventions recognized by the community of reference, a question that poorly combines with the need to develop uncommon languages and expressive models. Moreover, the collaboration with experts of multimedia graphic production has significant advantages and allows, amongst other things, for the creation of visual products having a high graphic impact, with advanced visualisation advantages: illustrations, infographics, 3D animations, videos and augmented reality are some of the most up-to-date instruments and languages.

The question is if both options are true. The scientist needs graphic-visual communicative competencies, both to search for different meanings giving shape to the ideas and to enter a conversation with a broad public; for the graphic products having a high level of specialisation, there is a need to collaborate with technicians of the sector to devise and realize communicative forms having a high social and democratic impact. Multimedia designers and artists are capable, thanks to their training, of communicating concepts and principles by identifying a specific target user and interacting with the public, considering the graphic-visual product as an integral part of the communicative project (Rodríguez Estrada, 2015; Frankel \& DePace, 2012; Davis, 2010; Murchie \& Diomede, 2020).

A possible collaboration between technicians and scientists, between visual operators and researchers, can be useful to find the communicative project and the most representative quality in relation to the research, just as training in the direction of the graphic-visual competencies can stimulate in the researcher the capacity to reinterpret the knowledge, allowing him/her to add new approaches and interpretations and to speak to different publics.

\section{Conclusions}

The analysis of the case studies leads us to position the competencies needed by the researcher in the space of interconnection between art and science, between visual language and scientific language. In this space, one can develop visual and creative thinking generative of new meanings, useful for finding a point of intersection with the many publics of reference (see Fig. 7).

The relationship between science and society has to be faced in the light of engagement, for an interpretation of the communicative action that is more egalitarian than the one underlying the concept of scientific dissemination. Upstream to this, there is the active involvement of scientists and citizens to arrive at more satisfactory results, to form a more solid relationship of trust between experts and the public and to a democratic formation of both active constructors of the public sphere. Upstream, there are also two theoretical fields, that of Didactics and Communication of scientific research, which can bring to bear contributions useful for finding methods and strategies for a process of construction of shared and participated knowledge (Bucchi, 2016; Feinstein, 2015; Fooladi, 2020). The researcher today probably cannot be exempted from knowing the main techniques of visual communications and from learning to communicate with a vast public, often not highly specialised, but in being a citizen, and thus a useful interlocutor. The activities of public engagement are deemed to be a responsibility of the research institutions and are inserted in the field of the third mission of the universities; the debate on which are the communicative models and languages most suited to achieving the aim and which should be the professionals involved is still open. This implies, on the one hand, the need to ensure scientific rigor, and on the other, the need to observe and record data in an original and meaningful way; on the one hand, the wish to communicate the research results and on the other, the discovery of a surprisingly active public participative in the construction of knowledge. Meeting in the third space of visual communication means this as well: hybridising several polarities between rigour and original gaze, known and unknown, singular and plural.

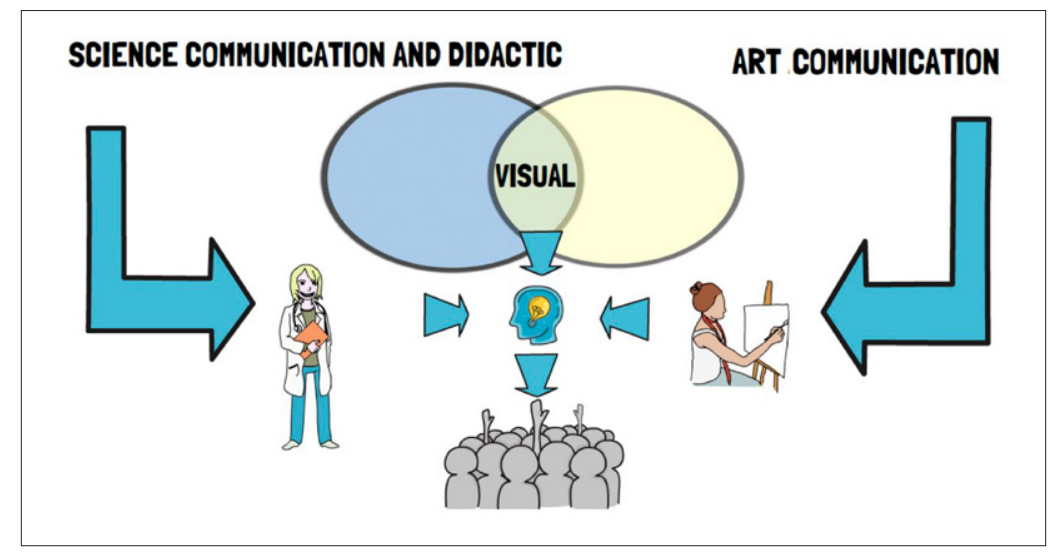

Fig. 7 Conclusion: graphical abstract 
Visual communication in research

Corazza, L., Macauda, A.

\section{Author Contributions:}

This contribution, developed and shared jointly by the two authors, was drawn up as follows: paragraphs 1 and 2 by Laura Corazza and paragraphs 3 and 4 by Anita Macauda. The conclusions were developed together by two authors.

\section{References}

Arnheim, R. (1974). Il pensiero visivo. La percezione visiva come attività conoscitiva. Torino: Einaudi.

Arnheim, R. (1984). Arte e percezione visiva. Milano: Feltrinelli.

Bucchi M., \& Trench, B. (2016). Science Communication and Science in Society: A Conceptual Review in Ten Keywords", Tecnoscienza, Vol 7, No 2.

Calabrese, O (1984). Il linguaggio dell'arte, Milano: Bompiani.

Calvani, A. (Ed.) (2011). Principi di comunicazione visiva e multimediale. Fare didattica con le immagini. Roma, Carocci.

Cheung, M. (2011). Creativity in advertising design education: An experimental study. Instructional Science, 39(6), 843864. https://doi.org/10.1007/s11251-010-9157-y-3.

Chiou, C.C., Tien, L.C., \& Lee, L.T. (2015). Effects on learning of multimedia animation combined with multidimensional concept maps. Computers \& Education, 80, 211-223.

Ciardi, M. (2019). Il segreto degli elementi. Mendeleev e l'invenzione del sistema periodico. Milano: Hoepli.

Cicalò, E. (2016), Intelligenza grafica, Roma: Aracne.

Clark, R. C., \& Lyons, C. (2010). Graphics for learning: Proven guidelines for planning, designing, and evaluating visuals in training materials. San Francisco, CA: Pfeiffer Wiley.

Corazza, L. (2010). Video e comunicazione scientifica. Ricerche di Pedagogia e Didattica, 5, 1-8

Corazza, L. (2012). I laboratori di Artelier. Un'esperienza educativa che diventa un film. Infanzia, 9, 231-234.

Corazza, L. (2017). Apprendere con i video digitali. Per una formazione online aperta a tutti. Milano: FrancoAngeli.

Corazza, L., \& Ferrari, L. (Ed.) (2012). Videoculture. Tra formazione, didattica e ricerca. Bologna: Clueb.

Corazza, L., \& Zanchettin, A. (2016). L'educatore di strada. Un mestiere invisibile portato alla luce da un documentario. Formazione \& Insegnamento, XI, 1, 305-314.

Corazza, L., Reggiani, A., Ferrari, L., Nenzioni, M., \& Mäkelä, M. (2018). Visualisation in a MOOC. The TOX-OER experience. In Ana Isabel Morales Martin (eds), Challenges in Open Educational Resources. The Case of TOX-OER MOOC. Salamanca: Editorial Amarante.

Davis, L. S. (2010). Science communication: A “down under” perspective. Japanese Journal of Science Communication, $7,65-71$.

Dewey, J. (1934). Art as experience. New York: Putnam.

Elgendi, M. (2017). Scientists need data visualisation training. Nature biotechnology, 35, 990-991. https://doi.org/10.1038/ nbt.3986

Evagorou, M., Erduran, S., \& Mäntylä, T. (2015). The role of visual representations in scientific practices: from conceptual understanding and knowledge generation to 'seeing' how science works. International Journal of STEM Education, 2, 1-13. https://doi.org/10.1186/s40594-015-0024-X

Feinstein, N.W. (2015). Education, Communication, and Science in the Public Sphere. Journal of Research in Science Teaching, 52(2) 145-163.

Fiorentino, E. (2018). Il vero, il bene e il bello: le immagini come occasione di apprendimento significativo. In S. Ulivieri, L. Binanti, S. Colazzo, M. Piccinno (Eds.), Scuola Democrazia Educazione. Formare ad una nuova società della conoscenza e della solidarietà. Lecce: PensaMultimedia.

Flessner, R. (2014). Revisiting Reflection: Utilizing Third Spaces in Teacher Education, The Educational Forum, 78 (3), 231-247.

Floridi, L. (1998). La logica e il pensiero visivo. Iride, 24(2), 343-358.

Fooladi, E.C. (2020). Between Education and Opinion-Making. Dialogue between Didactic/Didaktik Models from Science Education and Science Communication in the Times of a Pandemic. Science \& Education, 29, 1117-1138, https:// doi.org/10.1007/s11191-020-00156-0

Frankel, F., \& DePace, A. H. (2012). Visual strategies: A practical guide to graphics for scientists and engineers. New Haven, CT: Yale University Press. 
Gardner, H. (1983). Frames of Mind: The Theory of Multiple Intelligences, New York: Basic Books.

Giunta, L., Ben Guefrache, F., Dekoninck, E., Gopsill, J., O’Hare, J., \& Morosi, F. (2019). Investigating the Impact of Spatial Augmented Reality on Communication between Design Session Participants - A Pilot Study. Proceedings of the Design Society: International Conference on Engineering Design, 1(1), 1973-1982. doi:10.1017/dsi.2019.203

Greimas, A.-J. (1984). Sémiotique figurative et sémiotique plastique. In P. Fabbri, \& G., Marrone (Eds), Semiotica in nuce. Teoria del discorso (pp. 196-210). Roma; Meltemi.

Gutiérrez, K.D. (2008). Developing a sociocritical literacy in the third space, Reading Research Quarterly, 43 (2), $148-164$.

Hullman J., \& Bach B. (2018). Picturing Science: Design Patterns in Graphical Abstracts. In P. Chapman, G. Stapleton, A. Moktefi, S. Perez-Kriz, \& F. Bellucci (Eds.), Diagrammatic Representation and Inference. Diagrams 2018. Lecture Notes in Computer Science, vol 10871. Cham: Springer. https://doi.org/10.1007/978-3-319-91376-6_19

Ibrahim, A. (2018). Seeing is Believing: Using Visual Abstracts to Disseminate Scientific Research. American Journal of Gastroenterology, 113(4), 459-461. doi: 10.1038/ajg.2017.268

Jefferson, T. (2007). Cattive acque. John Snow e la vera storia del colera a Londra. Roma: Il Pensiero Scientifico.

Lane, S., Karatsolis, A., \& Bui, L. (2015). Graphical abstracts: a taxonomy and critique of an emerging genre. SIGDOC '15: Proceedings of the 33rd Annual International Conference on the Design of Communication, 41, 1-9. https://doi. org/10.1145/2775441.2775465

Latour, B. (2011). Visualisation and cognition: drawing things together. In H. Kuklick (ed.), Knowledge and Society Studies in the Sociology of Culture Past and Present (pp. 1-40), Greenwich: Jai Press.

Lever, F. (2019). Audiovisivo. In F. Lever, P. C. Rivoltella, \& A. Zanacchi (Eds.), La comunicazione. Dizionario di scienze e tecniche. Retrieved from www.lacomunicazione.it.

Lumbelli, L. (2012). Il ruolo della percezione visiva nell'apprendimento con animazioni. Form@re. Open Journal per la formazione in rete, 12(80), 21-26.

Macauda, A. (2020). Visual learning and education for augmented reality environments. Img journal, 2, 180-199.

Macauda, A. (2018). Augmented reality environments for teaching innovation. REM, 10, 17-25.

Marzano, A. (2017). Mappe concettuali dinamiche e processi di rimediazione in ambienti di apprendimento in rete. Formazione \& Insegnamento, 15(3), 245-278.

Miranda, S., \& Marzano, A. (2019). The augmented reality in the professional development: a systematic map.Form@ re. Open Journal per la formazione in rete, 19(3), 207-220

Murchie, K.J., \& Diomede D. (2020). Fundamentals of graphic design essential tools for effective visual science communication. FACETS, 5, 1. https://doi.org/10.1139/facets-2018-0049

Munari, B. (1968). Design e comunicazione visiva. Contributo a una metodologia didattica. Roma-Bari: Laterza.

Munari, B. (1971). Artista e Designer. Roma-Bari: Laterza.

Nah, S.-M, \& Lee, Y.-J. (2016). The Visual communication by Augmented Reality. Journal of Digital Convergence. 14(11), 507-512. https://doi.org/10.14400/JDC.2016.14.11.507

Nayak, S., \& Iwasa J.H (2019). Preparing scientists for a visual future. Visualisation is a powerful tool for research and communication but requires training and support. Embo. Reports, 20(11), 1-7.

Novak, J. D. (2001). L'apprendimento significativo: le mappe concettuali per creare e usare la conoscenza. Trento: Erickson.

Novak, J. D. (2012). Costruire mappe concettuali: strategie e metodi per utilizzarle nella didattica. Trento: Erickson.

Panciroli, C. (2020). Per una didattica integrata: il modello CLAS, in: Animazione digitale per la didattica (pp. 19-33). Milano: FrancoAngeli.

Panciroli, C., Corazza, L. \& Macauda, A. (2020). Visual-Graphic Learning, in: Proceedings of the 2nd International and Interdisciplinary Conference on Image and Imagination (pp. 49-62), Cham: Springer.

Panciroli, C., Macauda, A., \& Corazza, L. (2020), Costruire relazioni di conoscenza attraverso artefatti digitali, in: Animazione digitale per la didattica (pp. 37-49), Milano, FrancoAngeli.

Panciroli, C., \& Macauda, A. (2019). Feedback images in university teaching,Form@re. Open Journal per la formazione in rete, 19, 234-246.

Panciroli, C., \& Macauda, A. (2018). Educazione al patrimonio e realtà aumentata: quali prospettive, Giornale Italiano della Ricerca Educativa, XI, 47-62.

Pellegrini, M., \& Mensuali, A. (2015). L'efficacia delle mappe concettuali per l'apprendimento: analisi critica di evidenze empiriche, Form@re. Open Journal per la formazione in rete, 15(3), 129-141. http://dx.doi.org/ 10.13128 /formare-17154 
Pferschy-Wenzig, E-M., Pferschy, U., Wang D., Mocan, A., \& Atanasov, A.G. (2016). Does a Graphical Abstract Bring More Visibility to Your Paper? Molecules, 21(9), 1247. https://doi.org/10.3390/molecules21091247

Rastier, F. (2003). Arti e scienze del testo: per una semiotica delle culture. Roma: Meltemi.

Rivoltella, P.C. (2014). La previsione. Neuroscienze, apprendimento, didattica. Brescia: La Scuola.

Robertson, I. (2003). Intelligenza visiva. Il sesto senso che abbiamo dimenticato. Milano: Rizzoli.

Rodríguez Estrada, F.C., \& Davis, L.S. (2015). Improving Visual Communication of Science Through the Incorporation of Graphic Design Theories and Practices into Science Communication. Science Communication, 37(1) 140-148.

Salmi, H., Thuneberg, H., \& Vainikainen, M.-P. (2017) Making the invisible observable by Augmented Reality in informal science education context, International Journal of Science Education, 7(3), 253-268, http://dx.doi.org/10.1080/ 21548455.2016.1254358

Scamuzzi, S. (2015). Umanisti e scienziati: ancora due culture? In S. Scamuzzi e G. Tipaldo (Eds.), Apriti scienza. Il presente e il futuro della comunicazione della scienza in Italia tra vincoli e nuove sfide (pp. 235-252). Bologna: Il Mulino.

Shams, L., \& Kim, R. (2010). Crossmodal influences on visual perception. Physics of Life Reviews, 7(3), 269-284,

Tipaldo, G., \& Carriero, R. (2015). Comunicare la scienza. In S. Scamuzzi e G. Tipaldo (Eds.), Apriti scienza. Il presente e il futuro della comunicazione della scienza in Italia tra vincoli e nuove sfide (pp. 29-86). Bologna: Il Mulino.

Trentin, G. (2015). Mappe concettuali, flussi di conoscenza e sviluppo professionale continuo.Form@re. Open Journal per la formazione in rete, 15(2), 4-18. http://dx.doi.org/10.13128/formare-16990

Ulger, K. (2018). The Effect of Problem-Based Learning on the Creative Thinking and Critical Thinking Disposition of Students in Visual Arts Education. Interdisciplinary Journal of Problem-Based Learning, 12(1). https://doi. org/10.7771/1541-5015.1649

Williams, R., \& Newton, J. H. (2007). Visual communication: Integrating media, art, and science. New York, NY: Routledge.

Wray, C.M, \& Arora, V.M. (2017). \#VisualAbstract: A Revolution in Communicating Science? Ann Surg; doi: 10.1097/ SLA.0000000000002339. 